\title{
Fabrication of a Novel Nickel-Curcumin/Graphene Oxide Nanocomposites for Superior Electrocatalytic Activity toward the Detection of Toxic p-nitrophenol
}

\author{
Sasikumar Ragu ${ }^{1}$, Shen-Ming Chen ${ }^{1, *}$, Palraj Ranganathan ${ }^{2}$, Syang-Peng Rwei ${ }^{2}$ \\ ${ }^{1}$ Department of Chemical Engineering and Biotechnology, National Taipei University of Technology, \\ No. 1, Section 3, Chung-Hsiao East Road, Taipei 106, Taiwan, ROC. \\ ${ }^{2}$ Institute of Organic and Polymeric Materials, National Taipei University of Technology, No. 1, \\ Section 3, Chung-Hsiao East Road, Taipei 106, Taiwan, ROC. \\ *E-mail: smchen78@ms15.hinet.net
}

doi: $10.20964 / 2016.11 .09$

Received: 23 July 2016 / Accepted: 29 August 2016 / Published: 10 October 2016

The current study deals with the sensitive electrochemical sensor for ecologically harmful pNitrophenol (pNP) based on a glassy carbon electrode which was modified by nickel-curcumin $\left[\mathrm{Ni}(\mathrm{Curc})_{2}\right]$ /graphene oxide [GO]. The physicochemical properties of the as-prepared nanocomposites were characterized using a different analytical and spectroscopic method, which include UV-Vis spectrophotometer, fourier-transform infra-red spectrophotometer, field emission scanning electron microscopy and cyclic voltammetry. The reduction of $\mathrm{pNP}$ at modified GCE revealed linear range $0.49-760 \mu \mathrm{M}$, limit of detection $0.016 \mu \mathrm{M}$ and high sensitivity $0.671 \mu \mathrm{A} \mu \mathrm{M}^{-1} \mathrm{~cm}^{2}$. The recommended sensor was well developed and established the influence of low cost, easily prepare, which is greater to newly reported modified electrodes, thereby permissive practical industrial applications.

Keywords: Electrochemical, Curcumin, p-nitrophenol, Grapheme Oxide, Nickel nitrate, Cyclic voltammetry, Sensor

\section{$\underline{\text { FULL TEXT }}$}

(C) 2016 The Authors. Published by ESG (www.electrochemsci.org). This article is an open access article distributed under the terms and conditions of the Creative Commons Attribution license (http://creativecommons.org/licenses/by/4.0/). 